\title{
PROBLEMATIKA PEMBANGUNAN PEDESAAN
}

\author{
Oleh; Muslim, S.Sos, M.Si
}

\begin{abstract}
Abstrak
Pembangunan masyarakat desa merupakan proses dimana masyarakat desa dapat merencanakan atau menerima usaha-usaha pembaharuan dalam meningkatkan taraf hidup, tentunya perencanaan ini sebaiknya dilakukan oleh masyarakat desa itu sendiri. Pembangunan dilakukan menurut ketentuan yang telah ditetapkan oleh pemerintah pusat, kemudian diterapkan untuk setiap daerah dengan mengunakan pola yang sama tentu mendapat kendala, karena setiap daerah mempunyai karakterisrik lingkungan masyarakat yang berbeda-beda sehingga perlu diterapkan suatu sistem yang sesuai dengan karakteristik yang dimilikinya.
\end{abstract}

Kata Kunci : Pembangunan, Masyarakat Desa, Otonomi Daerah.

\section{A. Pendahuluan}

Pembangunan menurut Siagian adalah suatu usaha pertumbuhan dan perubahan yang berencana yang dilakukan secara sadar oleh suatu bangsa, negara dan pemerintah menuju modernitas dalam rangka membina bangsa (1982: 67). Artinya, bangsa yang ingin maju dan dapat bersaing dengan bangsa lain harus dapat merencanakan pertumbuhan dan perubahan. Perencanaan ini tentu dengan menggunakan cara atau metode ilmiah, keterbatasan bangsa kita dalam hal ini sangat kita rasakan terutama di daerah pedesaan.

Pembangunan masyarakat desa merupakan proses dimana masyarakat desa dapat merencanakan atau menerima usahausaha pembaharuan dalam meningkatkan taraf hidup, tentunya perencanaan ini sebaiknya dilakukan oleh masyarakat desa itu sendiri. Pembangunan dilakukan menurut ketentuan yang telah ditetapkan oleh pemerintah pusat, kemudian diterapkan untuk setiap daerah dengan mengunakan pola yang sama tentu mendapat kendala, karena setiap daerah mempunyai karakterisrik lingkungan masyarakat yang berbeda-beda sehingga perlu diterapkan suatu sistem yang sesuai dengan karakteristik yang dimilikinya. Masyarakat sebagai obyek dan subyek pembangunan harus diikut sertakan secara aktif dalam pembangunan dan menikmati hasil pembangunan serta melestarikan proses pembangunan itu sendiri secara berkesinambungan. Oleh karena itu, proses pembangunan secara alamia harus muncul dari masyarakat, dilaksanakan oleh masyarakat dan hasilnya dinikmati oleh masyarakat

Diakui bahwa pembangunan masyarakat desa merupakan hal yang sulit, di samping karena kurangnya modal, tingkat pendidikan yang rendah, ditambah lagi sifat homogenetis masyarakat desa sehingga lemahnya daya saing dan kurangnya tenaga yang dapat membimbing mereka kearah pembaharuan, namun semua itu harus diterima dan dipotensikan untuk mencari cara pemecahan yang akan dipergunakan untuk pembangunan desa.

Pasca bergulirnya reformasi, desentralisasi atau yang dikenal dengan otonomi daerah sangat populer di Indonesia. 
Daerah di Indonesia menuntut pelimpahan wewenang untuk mengatur dan mengurus daerahnya sendiri tanpa harus dikomandoi oleh pusat walaupun istilah ini sebenarnya sudah ada di Indonesia sejak awal kemerdekaan yaitu ditetapkannya Undangundang No. 1 tahun 1945 tentang Pemerintahan Daerah, dan bahkan sebelum Indonesia mardeka Pemerintahan Hindia Belanda sudah memberikan kewenangan kepada daerah tertentu untuk melakukan kegiatan pemerintahan tepatnya dimulai pada tahun 1903, namun tidak sekompleks seperti saat ini.

segar $\begin{gathered}\text { Pada saat ini daerah mendapat angin } \\ \text { ketika diperbesarnya porsi }\end{gathered}$ desentralisasi dibandingkan sebelumnya. Pelaksanaan otonomi daerah menjadi pembicaraan yang serius oleh pemerintah terutama pemerintah daerah, dan bahkan yang menjadi salah satu titik fokusnya ialah desa atau dikenal dengan istilah otonomi desa. Desa merupakan komunitas masyarakat yang mempunyai nilai hukum sangat tinggi dan mempunyai hak asal usul yang istimewa.

\section{Ditetapkannya Undang-undang}

Nomor 32 tahun 2004 tentang Pemerintahan Daerah yang merupakan revisi dari Undangundang 22 tahun 1999 menyebutkan bahwa desa merupakan otonomi asli bukan pemberian dari pemerintah. Desa memiliki kewenangan untuk menentukan sendiri corak pembangunannya yang sesuai dengan asalusul dan kebiasaan masyarakat setempat. Di desa juga dibentuk Badan Permusyawaratan Desa (BPD) yang berfungsi menetapkan Peraturan Desa (Perdes), menampung dan menyalurkan aspirasi masyarakat. Disamping itu juga desa dapat membentuk lembagalembaga lain yang sesuai dengan tuntutan dan kebutuhan.

Adanya otonomi desa ini diharapkan pembanguan desa dapat berjalan dengan baik, efektif dan efisien karena pembanguan dilakukan berdasarkan kehendak masyarakat setempat, sehingga partisipasi masyarakat dalam pembangunan desa dapat digalang sedemikian rupa. Partisipasi masyarakat merupakan salah satu elemen penting dalam proses pembangunan, oleh karena itu partisipasi masyarakat perlu dibangkitkan terlebih dahulu oleh pemerintahan desa, sebab partisipasi masyarakat merupakan salah satu sasaran pembangunan desa itu sendiri.

\section{B. Pembangunan}

Pembangunan pada hakekatnya adalah pertumbuhan plus perubahan karena yang melakukan pembangunan itu adalah manusia yang dikenal sebagai makhluk yang sangat dinamis dan tentu saja pertumbuhan dan perubahan dimaksud dapat membawa pengaruh yang positif bagi kehidupan masyarakat. Menurut Sasmita (dalam Riyadi, 2004 : 4) bahwa pembangunan merupakan suatu proses perubahan ke arah yang lebih baik melalui upaya yang dilakukan secara terencana.

Menurut Siagian (2005:4) pembangunan adalah suatu usaha atau rangkaian usaha pertumbuhan dan perubahan berencana yang dilakukan secara sadar oleh suatu bangsa, negara dan pemerintah, menuju modernitas dalam rangka pembinaan bangsa (nation building). Dari pengertian di atas pembangunan dapat diartikan sebagai perubahan menuju pola-pola masyarakat yang realistis dimana dampak dari pembangunan, masyarakat dapat lebih banyak mengenal hal-hal baru dan memungkinkan juga akan menggunakannya dalam kehidupan mereka serta mengubah prilaku. Perubahan tersebut dapat dicermati dari sikap, pola pikir dan kehidupan sosial ekonomi.

Selanjutnya Siagian (2005:4) juga menyampaikan bahwa pembangunan 
mengandung aspek yang sangat luas mencakup pembangunan dibidang politik, ekonomi, sosial budaya dan pertahanan dan keamanan. Pendapat ini ditegaskan juga oleh Tjokroamidjojo (dalam Kaho, 2005:125) bahwa pembangunan meliputi segala segi kehidupan, politik, ekonomi, dan sosial budaya. Semua ini baru akan berhasil apabila kegiatan yang melibatkan partisipasi dari seluruh masyarakat.

Dari pendapat ini dapat disimpulkan bahwa pembangunan seharusnya dilakukan disegala bidang kehidupan sehingga terjadi keseimbangan antara unsur satu dengan lainnya.

Di Indonesia istilah Trilogi Pembangunan cukup mengakar dan sering dibahas diberbagai pertemuan ilmiah. Trilogi Pembangunan ialah pembangunan yang meliputi tiga aspek penting yaitu pertumbuhan, pemerataan dan stabilitas. Menurut Sumitro (1985:4) yang dimaksud dengan pertumbuhan ialah usaha untuk meningkatkan produksi barang dan jasa di bidang yang semakin meluas dalam masyarakat sebagai keseluruhan. Pemerataan ialah suatu pembagian hasil produksi masyarakat yang lebih merata sehingga dirasakan lebih adil dalam kehidupan masyarakat. Sedangkan stabilitas, yaitu suasana kehidupan masyarakat yang stabil.

Sedangkan inti dari pembangunan disampaikan oleh Goulet (dalam Todaro, 1999 : 19) ada tiga unsur dimana ketiga hal inilah yang merupakan tujuan pokok yang harus dicapai oleh setiap orang dan masyarakat melalui pembangunan. Ketiganya berkaitan secara langsung dengan kebutuhankebutuhan manusia yang paling mendasar, yang terwujud dalam berbagai macam manifestasi (bentuk) di hampir semua masyarakat dan budaya sepanjang zaman. Adapun ketiga inti pembangunan tersebut ialah :

1. Kecukupan (sustenance), merupakan kemampuan seseorang atau sekelompok orang untuk dapat memenuhi kebutuhankebutuhan dasarnya, adapun yang dimaksud kebutuhan dasarnya ialah segala sesuatu yang jika tidak dipenuhi akan menghentikan kehidupan seseorang, kebutuhan ini meliputi pangan, sandang, papan, kesehatan dan keamanan

2. Jati diri (self-esteem) ialah dorongan dari diri sendiri untuk maju, untuk menghargai diri sendiri, untuk merasa diri pantas dan layak melakukan dan mengerjakan sesuatu, dan seterusnya.

3. Kebebasan (freedom) ialah kemampuan untuk dapat menentukan atau memilih, maksudnya kemampuan sesorang untuk terlepas dari sikap menghamba.

Lebih jauh Todaro (1999 : 51) mengatakan upaya untuk merealisasi inti pembangunan yang mengeluarkan manusia dari jerat tali kemiskinan mesti dengan dua langkah yaitu, meningkatkan tingkat pendapatan nasional rata-rata dan memperkecil kesenjangan dalam distribusi pendapatan.

Khususnya kesenjangan dalam distribusi pendapatan, masyarakat desa akan selalu mendapat kesenjangan karena berbagai macam bentuk keterbatasan dan di desa juga lah terdapatnya lumbung-lumbung kemiskinan tersebut. Todaro (1999: 353) mengutarakan bahwa di negara-negara Amerika Latin dan Asia, seperti Bolivia, Guatemala, India, Indonesia, Myanmar dan Filipina, diperkirakan labih dari separuh penduduknya hidup menetap di daerahdaerah pedesaan. Fakta yang lebih penting dari pada angka-angka tersebut adalah bahwasanya sebagian besar (hampir 70 persen) penduduk dunia yang miskin terdapat di wilayah pedesaan.

Pembangunan desa adalah pembangunan masyarakat desa sebagai upaya untuk merubah keadaan dari yang kurang dikehendaki menuju keadaan yang lebih baik 
(Ndraha, 1990:101). Selanjutnya Corolie (dalam Ndraha, 1990:15) mengartikan pembangunan sebagai upaya untuk meningkatkan kemampuan manusia untuk mempengaruhi masa depannya. Lebih lanjut dia mengatakan implikasi dari definisi tersebut yaitu :

1. Pembangunan berarti membangkitkan kemauan optimal manusia baik individu maupun kelompok (capacity)

2. Pembangunan berarti mendorong tumbuhnya kebersamaan dan kemerataan nilai dan kesejahteraan (Equity)

3. Menaruh kepercayaaan kepada masyarakat untuk membangun dirinya sendiri sesuai dengan kemapuan yang ada pada dirinya. Kepercayaan ini dinyatakan dalam bentuk kesempatan yang sama, kebebasan memilih dan kekuasaan untuk memutuskan (empowerment)

4. Pembangunan berarti membangkitkan kemampuan untuk membangun secara mandiri (sustainability)

5. Pembangunan berarti mengurangi ketergantungan negara yang satu dengan yang lainnya dan menciptakan hubungan yang saling menguntungkan dan menghormati (independence)

Pembangunan dilakukan oleh masyarakat sendiri dengan mengacu pada keinginan dan kebutuhan masyarakat akan lebih berdaya guna dari pada ditetapkan oleh pusat. Sebelum diberlakukannya UndangUndang No. 22 Tahun 1999 kemudian dirubah menjadi Undang-Undang No. 32 Tahun 2004, pembuatan keputusan sepenuhnya dimonopoli pusat, demikian pula hasil atau keuntungan yang diperoleh dialirkan ke pusat dan hanya sebagian kecil yang dikembalikan ke daerah serta persepsi dan kemauan pusat diterjemahkan ke dalam berbagai program pembangunan untuk diterapkan ke seluruh wilayah negeri ini.

Pada tatanan riil Adrews (2003:9) mengatakan dalam menelaah Indonesia, akan lebih banyak ditemukan berbagai kekuatan yang mendorong terjadinya fragmentasi ketimbang persatuan. Luas wilayah negeri ini yang mencapai 4,8 juta $\mathrm{Km}^{2}$ dengan 1,9 juta $\mathrm{Km}^{2}$ diantaranya merupakan dataran yang terpencar berupa 13.667 pulau dengan rentang jarak sekitar $5.110 \mathrm{Km}$ dari timur ke barat dan $1.880 \mathrm{Km}$ dari utara ke selatan, telah melahirkan berbagai kebhinekaan yang menjolok. Karenanya, tidaklah mengherankan apabila negeri ini ditandai oleh sejumlah perbedaan ekologi. Dari sudut sosial, Indonesia merupan negara yang ditandai oleh banyak hal yang kontras. Bagi orang luar Jawa, Jawa merupakan kelompok sosial dominan yang dipandang sebagai gambaran dari Indonesia, akan tetapi dalam kenyataannya terdapat sejumlah 300 kelompok etnis yang tersebar di seluruh wilayah Indonesia.

Suatu hal yang aneh dan mustahil ketika pembangunan dilakukan secara sama, tentunya mendapat daya tolak yang hebat dari masyarakat walaupun pada masa itu masyarakat tidak punya hak berpendapat karena otoritariannya rezim yang berkuasa. Sanit (dalam Kaho, 2005:126) menandaskan apabila kita berbicara mengenai pembangunan, sesungguhnya yang diperbincangkan ialah keterlibatan keseluruhan masyarakat sebagai sistem terhadap masalah yang dihadapinya dan pencarian jawaban bagi masalah tersebut. Keterlibatan masyarakat sebagai subyek pembangunan tentunya aktivitas pembangunan yang sesuai dengan kebutuhan dan keinginan masyarakat yang bersangkutan, ketika kebutuhan dan keinginan mereka diabaikan maka keterlibatan masyarakat ikut serta sebagai subyek pembangunan sulit untuk didapatkan.

Todaro (1999 : 353) menjelaskan bahwa di negara-negara Amerika Latin dan Asia, seperti Bolivia, Guatemala, India, Indonesia, Myanmar dan Filipina, 
diperkirakan lebih dari separuh penduduknya hidup menetap di daerah-daerah pedesaan. Fakta yang lebih penting dari pada angkaangka tersebut adalah bahwasanya sebagian besar (hampir 70 persen) penduduk dunia yang miskin terdapat di wilayah pedesaan.

Ketika kita berkaca kepada perkembangan kepustakaan tentang studi pembangunan menurut Chilcote (2004:13) sekurang-kurangnya ada lima katagori perkembangan studi pembangunan.

1. Konsep tradosional seperti teori tahapan pembangunan ekonomi karya Walk Rostow dan A.F.K. Organski dalam bukunya yang berjudul the Stages of Political Development

2. Studi yang memadukan konsepsi lama seperti nasionalisme dengan penafsiran baru tentang makna pembangunan itu sendiri, seperti karya Karl Detsch Nationalism and Social Communication

3. Teori tentang modernisasi, seperti Modernization and Structurre of Societies karya Marion J. Levy

4. Mencakup studi-studi perubahan, seperti tulisan Samuel P. Huntington Political order in Changging Societies, dan

5. Studi kritis yang kemudian muncul teoriteori pembangunan etnosentris, seperti tulisan Capitalism and Underdevelopment in Latin America karya Andre Gunder Frank dan How Europe Underdevelped Africa karya Walter Rodney.

Dari katagori yang kelima ini dapat diartikan bahwa pembangunan pada masa sekarang mestinya dilakukan berdasarkan pembangunan etnosentris dan ekologis, yaitu pembangunan yang berdasarkan sosial budaya dan asal usul masyarakat setempat.

\section{Permasalahan Pendidikan}

Semakin tinggi tingkat pendidikan seseorang maka semakin tinggi pulahlah tingkat kesadaran untuk melakukan upaya pembangunan baik bagi dirinya maupun lingkungannya, sebaliknya rendahnya tingkat pendidikan seseoarang berakibat rendahnya kesadaran untuk pembangunan.

Pendidikan sebagai salah satu unsur yang harus diperhatikan secara khusus oleh bangsa ini, agar pembangunan disegala bidang dapat terus dikembangkan dan pencapaian tujuan atau cita-cita luhur Bangsa Indonesia dapat terealisasi dengan baik, cepat dan tepat sebagaimana yang tertuang di dalam pembukaan Undang-Undang Dasar 1945 yaitu :

1. Melindungi segenap bangsa indonesia dan seluruh tumpah darah indonesia

2. Memajukan kesejahteraan umum, dan

3. Mencerdaskan kehidupan bangsa

Berkaca kepada negara-negara maju, tidak satu orang pun yang bisa membantah bahwa kemajun negara-negara tersebut sangat ditupang oleh pendidikan yang berkualitas, baik sistem pendidikan di dalam negerinya maupun melakukan upaya mengirim generasi muda (anak bangsa) terbaik mereka ke berbagai belahan dunia lain untuk menimba ilmu dan pada akhirnya mereka kembali untuk memajukan bangsanya. Sebagai contoh, hancur dan lantak luluhnya Jepang ketika diserang tentara sekutu pada Perang Dunia II, hampir tidak ada harapan untuk bangkit, namun kebijakan yang diambil untuk mengumpulkan para guru yang masih hidup, membawa Jepang menjadi negara yang terpandang dan bermarwah di dunia khususnya di asia pada saat ini.

Malaysia pada tahun 1970-an yang mendatangkan guru dari Indonesia, pada saat ini maju dan menjadi tempat yang diidamkan oleh sebagaian bangsa kita untuk menimba ilmu dan mencari kerja. Thailand yang belajar kepada Indonesia khususnya ilmu pertanian, pada saat ini hasil pertanian 
mereka sangat mengagumkan. Pada tahun 1980-an menjadi kebanggaan bagi orang Thailand ketika pagi harinya minum teh, dimana teh dan gulanya berasal dari pulau jawa, pada saat ini dengan rasa malu kita harus akui kita impor gula dari Thailand. Kedua negara tetangga kita ini berkembang dan bahkan meninggalkan negara gurunya yaitu Indonesia.

Di Indonesia terdapat 29 Juta Jiwa pemuda (19-25 tahun) sedangkan yang terdaftar sebagai mahasiswa di perguruan tinggi di seluruh indonesia hanya 3,1 Juta Jiwa (Edwar), lalu 25,9 Juta Jiwa yang lain sekarang ada dimana?, Di Propinsi Riau yang dikenal sebagai salah satu propinsi yang terkaya di Indonesia, terdapat 30,51\% (Badan Stratistik) masyarakat Riau yang hanya tamat Sekolah Dasar (SD) dan tidak tamat SD, dan dari angka yang pantastik tersebut sebagaian besar terdapat di daerah pedesaan.

Rendahnya sumber daya manusia dipedesaan tidak pernah terselesaikan dari dulu hingga sekarang dimana usia negara Indonesia sudah 67 tahun. Tidak terdapatnya sarana dan prasarana pendidikan yang cukup di daerah dan lemahnya motivasi masyarakat untuk melanjutkan pendidikan menjadi masalah besar yang terdapat dipedesaan. Sebagian kecil mereka yang melanjutkan pendidikan di Perguruan Tinggi yang ada di kota, enggan untuk pulang dan membanguan desanya. Hal ini disebabkan sudah termanjakan dengan suasana kota.

Data Akhir Tahun 2012

(Riauterkini.com), menyebutkan 11.043 Kelas di Riau Rusak. Daerah sekaya Riau bukan berarti membuat Provinsi Riau terbebas dari masalah ruang kelas rusak di sekolah-sekolah maupun madrasah. Buktinya, berdasarkan data yang dimiliki Dinas Pendidikan (Disdik) Provinsi Riau, hingga penghujung tahun 2012, tercatat setidaknya ada 11.043 ruang kelas yang tergolong rusak.
Dari jumlah tersebut, 6.985 ruang kelas diantaranya tergolong rusak ringan. Sementara 4.058 ruang kelas lainnya tergolong rusak berat. Berdasarkan data tersebut, diketahui bahwa ruang kelas rusak berat terbanyak ada di tingkat sekolah dasar (SD). Dimana, dari 21.137 ruang kelas di SD Negeri se-Riau, 2.334 ruang diantaranya tergolong rusak berat. Sementara di SD swasta jumlah yang rusak berat mencapai 164 ruang kelas. Untuk SD negeri, ruang kelas rusak berat ini kebanyakan ada di Kabupaten Indragiri Hilir dengan jumlah mencapai 624 ruang. Disusul Rohil dengan 438 ruang, Kampar 404 ruang dan Indragiri Hulu 194 ruang. Hanya Indragiri Hulu yang ruang kelas SD negeri-nya tak mengalami kerusakan. Baik ringan maupun berat. Sementara, untuk SD swasta, kebanyakan ruang rusak berat ditemukan di Rokan Hilir dengan 56 ruang, Inhil 32 ruang serta Kuantan Singingi 24 ruang.

Ruang kelas rusak berat juga banyak terdapat di tingkat SMP. Dimana, dari 4.802 SMP negeri, 265 ruang diantaranya dinyatakan tergolong rusak berat. Sementara, 724 ruang lainnya tergolong rusak ringan. Lalu, di SMP swasta, 150 ruang rusak berat dan 185 ruang tergolong rusak ringan. Kabupaten Kampar menjadi lokasi terbanyak ditemukannya ruang kelas SMP negeri yang rusak berat. Yaitu mencapai 61 ruang kelas. Lalu, di Rokan Hilir 48 ruang, Kuantan Singingi 38 ruang dan Bengkalis 36 ruang. Pekanbaru yang termasuk kota besar pun tak luput dari masalah ini. Dimana terdapat 35 ruang kelas SMP yang rusak berat di Kota Bertuah ini. Untuk kategori SMP swasta, terbanyak ada di Indragiri Hilir dengan jumlah 84 ruang, Rokan Hilir 40 ruang serta Siak dan Dumai masing-masing 6 ruang.

Dari data yang sama, Kabupaten Kuantan Singingi juga tercatat berada di posisi teratas untuk daerah yang memiliki ruang kelas rusak berat tingkat SMA, SMK dan Madrasah Aliyah (MA) negeri. Dimana, 
untuk tingkat SMA, tercatat ada 42 ruang kelas yang rusak berat. Tingkat SMK 24 ruang dan MA 7 ruang. Di tingkat Raudatul Adhfal (RA) swasta, Kuantan Singingi lagilagi menempati posisi teratas dengan jumlah ruang rusak berat 10 ruang.

Dari data tersebut dapat diyakini bahwa sekolah dan madrasah yang mengalami kerusakan baik berat maupun ringan, akan banyak dijumpai di daerah pedesaan, dan menjadi anggapan yang sudah biasa hal itu terjadi di Indonesia.

\section{Permasalahan Ekonomi}

Pembangunan ekonomi adalah suatu proses kenaikan pendapatan total dan pendapatan perkapita dengan memperhitungkan adanya pertambahan penduduk dan disertai dengan perubahan fundamental dalam struktur ekonomi suatu negara. Pembangunan ekonomi tak dapat lepas dari pertumbuhan ekonomi (economic growth), pembangunan ekonomi mendorong pertumbuhan ekonomi, dan sebaliknya, pertumbuhan ekonomi memperlancar proses pembangunan ekonomi, yang dimaksud dengan pertumbuhan ekonomi adalah proses kenaikan kapasitas produksi suatu perekonomian yang diwujudkan dalam bentuk kenaikan pendapatan nasional. Suatu negara dikatakan mengalami pertumbuhan ekonomi apabila terjadi peningkatan GNP riil di negara tersebut. Adanya pertumbuhan ekonomi merupakan indikasi keberhasilan pembangunan ekonomi.

Hampir diseluruh Indonesia investasi swasta maupun pemerintah selama ini cenderung terkonsentrasi di daerah perkotaan, pertumbuhan pasar diperkotaan memang tidak terkait dengan pedesaan di sekitarnya. Sebut saja sistem distribusi dari desa ke kota juga masih tidak efisien. Hal itu diperparah dengan infrastruktur jalan yang tidak memadai serta kondisi pasar yang belum memenuhi kebutuhan industri pengolahan dan perdagangan dipedesaan.
Kondisi itu mengakibatkan kondisi sosial ekonomi masyarakat pedesaan jauh tertinggal dibanding masyarakat yang tinggal diperkotaan. Padahal hampir sebagian besar masyarakat kita tinggal dipedesaan dengan sumber pendapatan utama dari sektor pertanian, akan tetapi kenapa perekonomian dipedesaan tertinggal, hal tersebut selalu menjadi pertanyaan yang hingga saat ini belum ditemukan jawabannya, meskipun dalam teori telah digambarkan ragam cara untuk melakukan perubahan yang mengarah terhadap perbaikan ekonomi pedesaan.

Kita tahu jumlah penduduk dan angka tenaga kerja dipedesaan tiap tahun terus bertambah, akan tetapi lapangan kerja ataupun usaha tidak berkembang yang mengakibatkan pengangguran terus bertambah. Akibatnya generasi muda dipedesaan lari keperkotaan hanya untuk mengadu nasib, hal itu tentunya akan berdampak terhadap hilangan sumber daya manusia potensial dipedesaan, sehingga siapa yang akan membangun daerah pedesaan, aktivitas ekonomi dipedesaanpun terus tertinggal. Sehingga dengan kondisi ini Pemerintah bukan hanya sadar dan tahu tentang itu akan tetapi harus dibuktikan dengan melakukan tindakan pelaksanaan melakukan pembangunan ekonomi dipedesaan dan memamfaatkan SDM yang ada.

Semua pihak pasti tahu dan mengerti dengan majunya pembangunan ekonomi pedesaan akan berdampak terhadap terjadinya percepatan pembangunan dan memicu terhadap munculnya pertumbuhan wilayah-wilayah strategis dipedesaan, nah dengan demikian tentunya akan tercipta sebuah pertumbuhan pembangunan ekonomi yang sinergis, tanpa limitasi batas wilayah administrasi. Salah satu upaya yang biasa dilakukan ialah dengan cara menghidupkan dan mengoptmalkan fungsi koperasi, hal ini bisa dijadikan alat yang sangat bermamfaat dalam mengembangkan ekonomi dipedesaan. 
Koperasi bisa dijadikan alat yang sangat bermamfaat dalam mengembangkan ekonomi dipedesaan. Desa di Indonesia yang mayoritas bergerak pada sektor pertanian, maka koperasi pertanian yang mesti dikembangan. Dinas Pertanian Perkebunan dan Holtikultura dalam hal ini jauh memiliki peranan penting dalam pengembangannya dari mulai pembibitan dan penanaman. Selanjutnya Dinas Perindustrian dan Perdagangan mulai dari pascapanen hingga kepamasaran harus andil bagian karena dinas ini juga harus mampu menciptakan alat-alat pengembangan produksi pertanian. Hal ini sudah diterapkan oleh Fadel Muuhammad di Gorontalo dinama pemerintah memprotek petani dari teknik cilik perdagangan para tengkulak yang membeli hasil pertanian rakyat dipedesaan dan menjual dengan harga yang tinggi diperkotaan.

Kita tahu tujuan pertumbuhan ekonomi pedesaan yang berkesinambungan ini akan menumbuhkan investasi di pedesaan, meningkatkan daya saing antara daerah pedesaan serta mengurangi ketimpangan pembangunan antar wilayah desa serta memenuhi kebutuhan masyarakat.

\section{F. Penutup}

Pembangunan masyarakat desa merupakan proses dimana masyarakat desa dapat merencanakan atau menerima usahausaha pembaharuan dalam meningkatkan taraf hidup, tentunya perencanaan ini sebaiknya dilakukan oleh masyarakat desa itu sendiri. Pembangunan ini tentu didukung oleh sumberdaya manusia yang dapat melihat peluang dan potensi desa, sehingga pembangunan desa dapat dilakukan dan dilaksanakan sesuai dengan kehendak dan kebutuhan masyarakat desa. Hal ini tentu akan berdampak kepada pertumbuhan ekonomi masyarakat, karena hampir diseluruh Indonesia investasi swasta maupun pemerintah selama ini cenderung terkonsentrasi di daerah perkotaan, pertumbuhan pasar diperkotaan memang tidak terkait dengan pedesaan di sekitarnya. Sebut saja sistem distribusi dari desa ke kota juga masih tidak efisien. Hal itu diperparah dengan infrastruktur jalan yang tidak memadai serta kondisi pasar yang belum memenuhi kebutuhan industri pengolahan dan perdagangan dipedesaan.

\section{Daftar Pustaka}

Chilcote, Ronald. H. 2004. Teori Perbandingan Politik. Jakarta : PT Raja Grapindo Persada.

Djojohadikusumo, Sumitro. 1985. Trilogi Pembangunan dan Ekonomi Pancasila. Jakarta : IKPN-RI.

Huntington. Samuel P. 2003. Tertib Politik di Tengah Pergeseran Kepentingan Massa. Jakarta : PT Raja Grapindo Persada.

Juliantara, Dadang. 2001. Pergeseran Negara dan Masyarakat Dalam Desa.Yogyakarta : Lapera Pestaka Utama.

Kaho, Josef Riwu. 2005. Prospek Otonomi Daerah di Negara Republik Indonesia. Jakarta : PT Raja Grapindo Persada

Kuncoro, Mujarat. 2004. Otonomi dan Pembangunan Daerah. Jakatra : Erlangga 
MacAndrews, Colin. \& Ichlasul Amal. 2003. Hubungan Pusat - Daerah dalam Pembangunan. Jakarta: PT Raja Grapindo Persada.

Ndraha, Taziluduhu. 1990. Pembangunan Masyarakat. Jakarta : Reneka Cipta

Riady. 2004. Perencanaan Pembangunan Daerah. Jakarta : Gramedia
Todaro, Michael. P. 1999. Pembangunan Ekonomi di Dunia Ketiga. Jakarta : Erlangga.

Widjaja, HAW. 2002. Otonomi Daerah dan Daerah Otonom. Jakarta: PT Raja Grapindo Persada.

$2003 . \quad$ Pemerintahan
Desa/Marga. Jakarta: PT Raja
Grapindo Persada.

